\title{
RANCANG BANGUN SISTEM INFORMASI POS (POINT OF SALE) UNTUK KASIR MENGGUNAKAN KONSEP BAHASA PEMROGRAMAN ORIENTASI OBJEK
}

\author{
Samsir $^{1)}$, Muhammad Siddik ${ }^{2)}$ \\ ${ }^{1}$ Prodi Teknik Informatika, FakultasTeknik, Universitas Al-Washliyah Labuhanbatu \\ ${ }^{2}$ Prodi Teknik Informatika, Fakultas Ilmu Komputer, Institut Binis dan Teknologi Pelita Indonesia \\ Email: ${ }^{1}$ samsirst111@gmail.com, ${ }^{2}$ siddik@ lecturer.pelitaindonesia.ac.id
}

\begin{abstract}
Cafe Filoscoffee is a place of business in the culinary field that is much in demand by visitors. This cafe has constraints in the sales transaction system and the processing of recapitulation reports on the sales transaction due to not utilizing the Point of Sales (POS) application system. The role of the cashier that is still quite simple, such as the addition and subtraction of transactions, still uses a calculator which is not done automatically and often inhibits sales transactions. The POS is designed and built for the purpose of recording sales transactions and processing inventory data so that it helps improve operational performance and accelerates the service process. The POS information system was built using the Object Orientation Programming (OOP) language. This system is able to process all sales transaction data. The process of addition and subtraction can be done more quickly, precisely and accurately so as to avoid the risk of errors in financial calculations and data collection of goods, this system can also carry out the process of searching data, storing data, grouping data so that in making reports can run effectively and efficiently.
\end{abstract}

Keywords: Information System, Cashier, OOP, POS

\begin{abstract}
Abstrak
Kafe Filoscoffee merupakan tempat usaha di bidang kuliner yang banyak diminati oleh pengunjung. Kafe ini memiliki kendala dalam sistem transaksi penjulan dan pengolahan data rekapitulasi laporan transaksi penjulan dikarenakan belum memanfaatkan sistem aplikasi Point of Sales (POS). Peran kasir yang masih cukup sederhana seperti proses penjumlahan dan pengurangan transaksi masih menggunakan kalkulator yang mana tidak dikerjakan secara otomatis dan sering menghambat transaksi penjualan. POS yang dirancang dan dibagun bertujuan mencatat transaksi penjualan dan mengolahan data stok barang sehingga membantu meningkatkan kinerja kegiatan operasional dan mempercepat proses pelayanan. Sistem informasi POS dibangun menggunakan bahasa Pemrograman Orientasi Objek (OOP) sistem ini mampu mengolah semua data transaksi penjualan. Proses penjumlahan dan pengurangan dapat dilakukan lebih cepat, tepat dan akurat sehingga terhindar dari resiko kesalahan dalam perhitungan keuangan serta pendataan stok barang, Sistem ini juga dapat melakukan proses pencarian data, penyimpanan data, pengelompokkan data sehingga dalam pembuatan laporan dapat berberjalan dengan efektif dan efisien.
\end{abstract}

Kata kunci: Sistem Informasi, Kasir, OOP, POS 


\section{PENDAHULUAN}

Definisi sistem menurut Wing dalam bukunya sistem informasi manajemen menyebutkan bahwa: "Sistem adalah suatu komponen yang saling berkerja sama untuk mencapai suatu tujuan. Fungsi sistem yang utama menerima masukan, mengolah masukan, dan menghasilkan keluaran. Informasi adalah data yang diolah sehingga berguna untuk pembuatan keputusan". (Siddik \& Sirait, 2018).

Sistem informasi menurut Sutarman dalam bukunya pengantar teknologi informasi menyebutkan : "Satuan komponen yang saling berhubungan mengumpulkan, memproses, menyimpan, menganalisis, menyebarkan informasi untuk tujuan tertentu. Seperti sistem lainnya, sebuah sistem informasi terdiri atas input (data instruksi) dan output (laporan, kalkulasi). Sistem informasi memproses input dan menghasilkan output yang dikirim kepada pengguna atau sistem yang lainnya”.

Kasir adalah seseorang yang pekerjaannya menerima uang pembayaran saat pembelian produk barang atau jasa dan melakukan pengembalian uang sisa pembayaran, sekaligus menyerahkan produk barang atau jasa kepada pelanggan (customer) di loket-loket kasir di suatu toko, super market, mini market, hotel, restoran, rumah sakit, ataupun department store. (Galih Wisnu W \& Robby, 2016).

Selain itu peran kasir mampu meningkatkan efisiensi kinerja terhadap pelayanan kepada konsumen serta pemanfaatan komputerisasi yang optimal dalam pendataan stok barang. (Kuncoro, 2015)

Point of Sale (POS) adalah sebuah sistem informasi yang memungkinkan untuk transaksi, yang didalamnya termasuk juga penggunaan mesin kasir. Dalam lingkup POS, sebuah mesin kasir tidak berdiri sendiri namun sudah termasuk di dalamnya software penunjang dan piranti lain. Sistem POS melakukan lebih dari sekedar transaksi jual beli, didalamnya juga bisa terintegrasi perhitungan akuntansi, manajemen barang dan stok, modul penggajian karyawan, perhitungan hutang piutang, dan berbagai macam fungsi lainnya. (Pamungkas \& Yuliansyah, 2017)

Kafe Filoscoffee yang berada di Marbau Labuhanbatu Utara, merupakan tempat usaha di bidang kuliner yang banyak diminati oleh pengunjung. Untuk menikmati sajian kuliner di kafe Filoscoffee ini, konsumen harus memesan secara manual dengan melihat menu yang ada di selebaran buku menu, dengan dibatu pelayan kafe akan membuatkan nota pemesanan. Pada saat konsumen ingin melakukan pembayaran, kasir mencatat nota pemesanan ke dalam buku besar yang berguna untuk mengetahui laporan penjualan, kemudian kasir menghitung transaksi pembayaran dengan kalkulator. Meski telah menggunakan kalkulator perhitungan transaksi masih memiliki kelemahan dalam perhitungan karena tidak jarang kasir melakukan kesalahan dalam memasukkan angka sehingga mengalami kerugian.

Melihat kasir berperan besar terhadap pelayanan kepada konsumen serta dapat membantu pertumbuhan usaha maka dibangun suatu sistem informasi POS yang dapat mengatasi masalah tersebut karena POS terdiri dari hardware berupa (Terminal/PC, Receipt Printer, Cash Drawer, Terminal pembayaran, Barcode Scanner) dan software berupa (Inventory Management, Pelaporan, Purchasing, Customer Management, Standar Keamanan Transaksi, Return Processing) dimana kedua komponen tersebut digunakan untuk setiap proses transaksi. POS akan menjadi sangat penting di dunia bisnis karena POS diibaratkan berupa terminal uang dimana tempat menerima pembayaran dari pembeli kepada pedagang, karena pembayaran tersebut merupakan indikator bagi pebisnis untuk mengukur tingkat pendapatan. (Marisa \& Yuarita, 2017)

Pemrograman berorientasi objek atau Object Oriented Programming (OOP) menurut Andi dalam bukunya analisa dan perancangan sistem informasi dengan metodologi berorientasi objek menyebutkan bahwa: "Pemrograman Berorientasi Objek (OOP) adalah suatu cara baru dalam berpikir serta berlogika dalam menghadapi masalahmasalah yang akan dicoba atasi dengan bantuan komputer, dimana setiap objek 
adalah entitas tunggal yang memiliki kombinasi struktur data dan fungsi tertentu. Sedangkan objek adalah orang, tempat, benda, kejadian, objek sebuah kejadian seperti pembayaran uang pendidikan, registrasi biodata siswa, membaca buku dan sebagainya. (Siddik \& Sirait, 2018).

Implementasi konsep pemrograman berorientasi objek pernah digunakan pada aplikasi sistem parkir menggunakan bahasa pemrograman java untuk memberikan kenyamanan bagi pengguna parkir dan membuat kinerja petugas parkir lebih efisien. (Ilham \& Naziro, 2019)

Menurut Ketut Darmayuda dalam bukunya aplikasi basis data dengan Visual Basic .NET menyebutkan "salah satu bahasa pemrograman yang mendukung OOP adalah Microsoft Visual Basic Studio .NET merupakan pengembangan kelanjutan dari Microsoft Visual Basic Studio .NET Framework 4.0 dengan berbasis Graphical User Interface (GUI).

\section{METODOLOGI PENELITIAN}

Metode penelitian yang digunakan untuk pengembangan perangkat lunaknya yaitu menggunakan model air terjun (waterfall) atau metodologi System Development Life Cycle (SDLC)

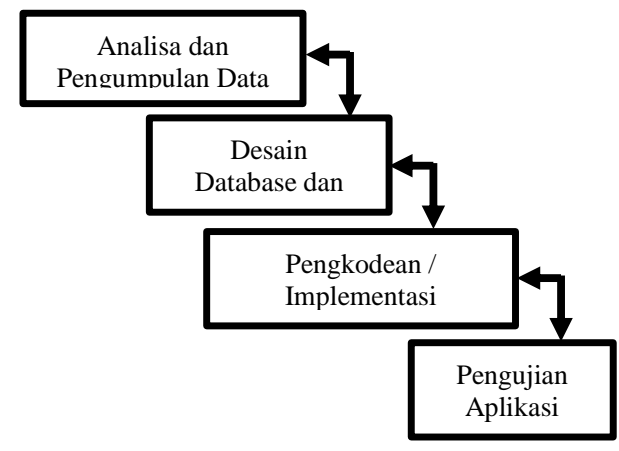

Gambar 1. Kerangka Penelitian

Analisis dan pengumpulan data, metode ini digunakan untuk menganalisis kebutuhan sistem yang dirancang sehingga dalam pembuatan program dapat berjalan dengan optimal, misalnya hardware dan software yang akan digunakan. Pengkodean nama makanan dan minuman yang nanti berkaitan dengan harga dari masing-masing item yang dijual. Perancangan sistem informasi Point of Sale (POS) untuk kasir ini menggunakan bahasa pemrograman Visual Basic Studio .NET dalam pembuatan aplikasi, sedangkan untuk desain database menggunakan MySQL, dalam menganalisa database perlu dirancang entitas, atribut dan hubungan antar entitas dengan menetapkan kunci primary key pada salah satu field. Tahap pengkodean atau implementasi aplikasi menggunakan penerapan dari OOP. Tahap terakhir adalah tahap pengujian aplikasi, dilakukan untuk memastikan bahwa software yang dibuat telah sesuai dengan desain dan semua fungsi dapat dipergunakan dengan baik tanpa ada error guna dapat memproses perhitungan, validasi dan verifikasi data, dengan harapan aplikasi ini dapat memenuhi kebutuhan yang mendasari perancangan dan pengembangan software.

\section{HASIL DAN PEMBAHASAN}

Hasil dan pembahasan penelitian yang tergambar sebagai berikut:

\subsection{Analisa Sistem yang Berjalan}

Menganalisa suatu sistem yang sedang berjalan merupakan salah satu tahap untuk menganalisa kebutuhan sistem dirancang akankah sesuai dengan tujuan utama sistem itu sendiri yaitu mempermudah pengguna sistem.

Prosedur sistem pelayanan kasir terhadap konsumen yang berjalan pada kafe Filoscoffee adalah sebagai berikut:

1. Konsumen memesan menu makan dan minuman yang tersedia di dalam selebaran buku menu.

2. Pelayan mencatat semua pesanan konsumen ke dalam sebuah nota pemesanan.

3. Sebelum konsumen membayar makanan dan minuman kasir harus mencatat nota pemesanan ke dalam sebuah buku besar.

4. Kasir menghitung semua transaksi pembayaran menggunakan kalkulator.

5. Konsumen membayar makanan dan minuman yang telah dipesan berdasarkan nota pemesanan yang telah di hitung oleh kasir.

6. Stok bahan baku dalam pembuatan makanan dan minuman sering kehabisan sehingga konsumen merasa kecewa pesanan tidak tersedia. 


\subsection{Analisa Kelemahan Sistem yang Berjalan}

Berdasarkan analisa yang dilakukan tentang sistem pelayanan kasir di kafe Filoscoffee, ada beberapa kekurangan pada sistem yang sedang berjalan, yaitu sebagai berikut:

1. Pemesanan makanan dan minuman masih menggunakan selebaran menu dan dicatat ke dalam sebuah nota pemesanan oleh pelayan.

2. Pencatatan nota pemesanan ke dalam buku besar akan memakan waktu yang cukup lama, karena di kerjakan masih secara manual dicatat berdasarkan jenis makanan dan minuman yang dipesan.

3. Terjadi antrian pada saat proses pembayaran di kasir karena adanya pencatatan nota pemesanan.

4. Perhitungan transaksi dengan menggunakan kalkulator masih memiliki kelemahan karena tidak jarang kasir melakukan kesalahan dalam memasukkan angka sehingga mengalami kerugian.

5. Kesalahan pada saat proses transaksi pembayaran bisa terjadi dan ini menyebabkan komplain dari konsumen apabila ada ketidak cocokan jumlah pembayaran dengan yang dipesan oleh konsumen, karena tidak ada bukti transaksi yang tercetak (struk) yang dapat diberikan kepada konsumen.

6. Pencatatan hasil penjualan masih dilakukan ke dalam buku besar yang berguna dalam pembuatan laporan penjualan ini akan sangat beresiko apabila buku tersebut hilang ataupun rusak.

7. Diperlukan banyak buku dan rak arsip dalam mengurutkan buku besar ini berdasarkan tanggal, bulan dan tahun penjualan.

8. Pembuatan laporan penjualan akan memakan waktu yang cukup lama karena pemilik kafe harus mengkalkulasikan ulang apa yang ada di dalam buku besar berdasarkan tanggal, bulan dan tahun penjualan.

9. Tidak terkontrolnya persediaan stok bahan baku dalam pembuatan makanan dan minuman sehingga pada saat konsumen memesan salah satu pesanan bahan bakunya tidak tersedia di tempat persediaan (gudang).

10. Resiko kehilangan buku besar akan berakibat fatal bagi si pemilik kafe (outner) karena tidak bisa membuat laporan penjualan.

\subsection{Analisa Sistem Usulan}

Berdasarkan hasil analisa yang telah dilakukan, maka dibutuhkan suatu sistem informasi kasir yang bisa mengatasi masalah yang terjadi. Sistem informasi Point of Sale (POS) dibangun menggunakan bahasa Pemrograman Orientasi Objek (OOP) menggunakan Database Management System (DBMS) dengan tujuan antara lain yaitu:

1. Mempermudah kegiatan transaksi pembayaran sehingga konsumen tidak perlu antri terlalu lama di bagian kasir pada saat sedang ramai.

2. Proses penjumlahan dan pengurangan dapat dilakukan lebih cepat, dan akurat agar terhindar dari resiko kesalahan dalam perhitungan keuangan.

3. Sistem ini dapat mencetak struk pembayaran sehingga konsumen merasa puas mereka tahu apa yang mereka makan dan minum berapa biaya setiap item pemesanan dan total pembayaran juga akan tercatat di sana secara otomatis, sehingga kalau terjadi kesalahan pada saat proses penginputan data oleh kasir konsumen bisa komplain berdasarkan struk yang ada.

4. Sistem informasi kasir ini mampu mengolah stok persediaan bahan baku pembuatan makanan dan minuman sehingga nantinya dapat mengakomodir permintaan konsumen akan pesanan menu yang tersedia.

5. Data transaksi penjualan tercatat secara otomatis di dalam database sehingga proses pembuatan pembuatan laporan penjualan yang bervariasi dapat dilakukan dengan cepat, tepat dan berkualitas.

6. Dapat mengatasi penyebaran data yang tersimpan di dalam rak - rak buku, kini semua data akan tersimpan di dalam media penyimpanan digital yaitu harddisk. 


\subsection{Perancangan Antar Muka \\ 1. Tampilan Login}

Sebelum masuk ke Menu Utama, pengguna harus terlebih dahulu login dengan akun yang sudah tersimpan di dalam sistem.

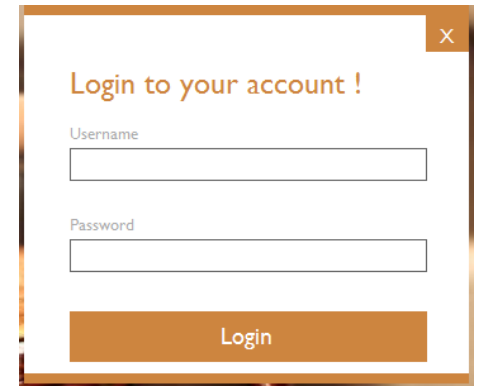

Gambar 2. Login awal program

\section{Tampilan Menu Utama}

Menu Utama merupakan menu yang menampilkan seluruh menu dan sub menu yang ada di dalam program.

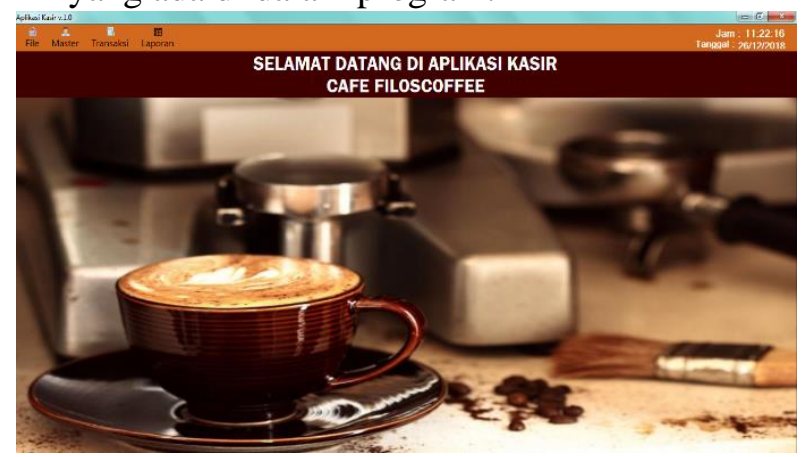

Gambar 3. Tampilan menu utama

\section{Tampilan Menu Master}

Menu Master terdiri dari 2 submenu yaitu:

a. Menu Administrator

Menu ini hanya untuk level admin yang dapat mengakses, dan user lain tidak dapat membuka menu ini.

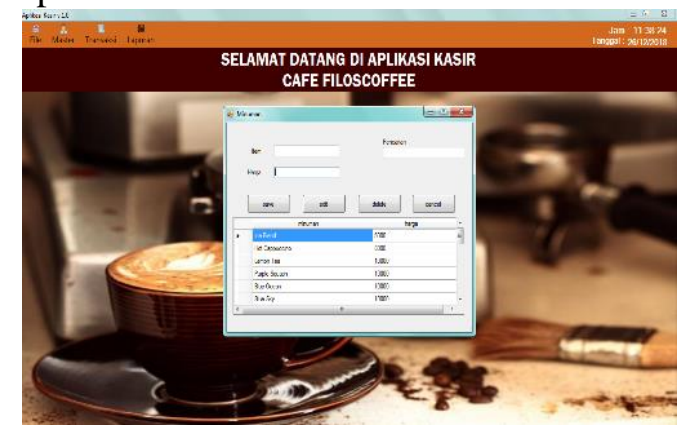

Gambar 4. Tampilan menu administrator b. Menu Barang (Makanan dan Minuman)

Di dalam menu ini admin dapat mengatur nama makanan dan minuman beserta harga, apabila suatu saat ada perubahan menu dan harga.

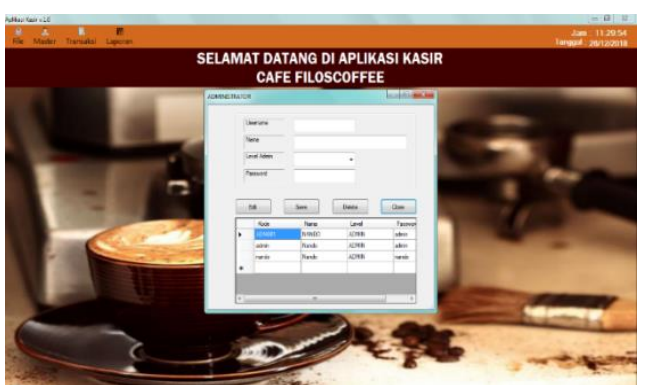

Gambar 5. Tampilan menu barang

\section{Tampilan Menu Transaksi}

Menu transaksi merupakan menu yang terdapat sebuah program kasir, atau dengan kata lain menu ini merupakan menu inti dari program ini. Di dalam menu ini seluruh kegiatan transaksi dilakukan. Menu transaksi ini bisa diakses oleh seluruh user yang sudah terdata di dalam database.

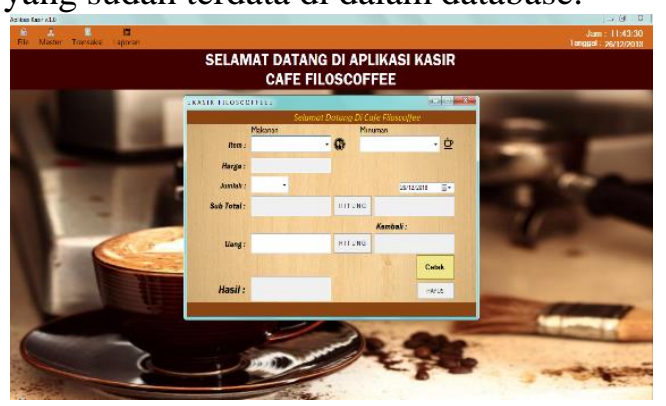

Gambar 6 Tampilan menu transaksi

\section{Tampilan Menu Laporan}

Menu laporan merupakan menu yang menampung seluruh transaksi yang dilakukan pada menu transaksi. Seluruh data penjualan dapat dilihat pada menu ini. Namun tidak semua user bisa mengakses menu ini, hanya pengguna level admin yang dapat mengaksesnya. Di dalam menu ini juga pengguna dapat mencari hasil penjualan berdasarkan tanggal penjualan. Dan seluruh data yang ada di dalam menu ini terkoneksi langsung ke database. 


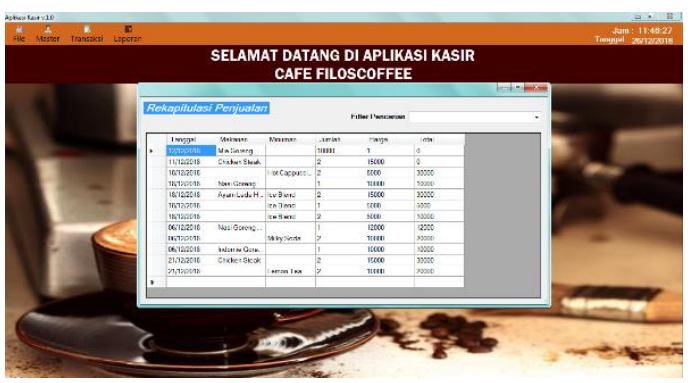

Gambar 7. Tampilan menu laporan

\section{Tampilan Struk Pembayaran}

Setelah selesai menghitung seluruh transaksi, maka seluruh data tadi akan ditampung pada sebuah lembar kerja yang bisa dicetak untuk diberikan kepada pembeli ataupun konsumen sebagai tanda bukti.

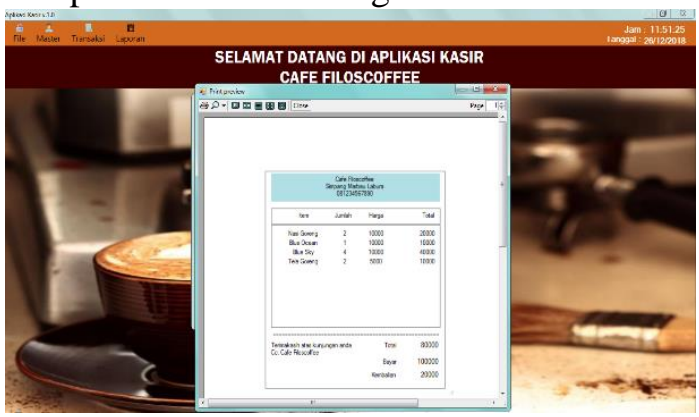

Gambar 8. Tampilan struk pembayaran

\section{SIMPULAN}

Konsep OOP pada sistem aplikasi POS untuk kasir memiliki kegunaan dalam meningkatkan kinerja dan pelayanan karena seluruh proses pencatatan transaksi penjualan, pendatataan stok barang, pencarian data, pengolahan data, pembuatan laporan, serta penyimpanan data dapat berjalan dengan efektif dan efisien dikarenakan seluruh data transaksi penjualan tersimpan di dalam satu database yang terkomputerisasi sehingga keterlambatan akan informasi kepada pemilik kafe dan pelanggan dapat teratasi.

\section{UCAPAN TERIMAKASIH}

Dalam proses menyelesaikan penelitian ini kami mengucapkan terima kasih kepada Universitas Al-Washliyah Labuhanbatu, Institut Binis dan Teknologi Pelita Indonesia dan kafe Filoscoffee yang telah bersedia memberikan data-data yang dibutuhkan yang berkaitan dengan penelitian ini, sehingga penelitian ini dapat diselesaikan.

\section{DAFTAR PUSTAKA}

Galih Wisnu W, \& Robby, R. (2016). Sistem Informasi Kasir di Hokky Waroeng Dimsum Surakarta. 5(4).

Ilham, N. A., \& Naziro. (2019). Implementasi Konsep Pemrograman Berorientasi Objek Pada Aplikasi Sistem Parkir Menggunakan Bahasa Pemrograman Java. 3(2), 63-69.

Ketut Darmayuda, Aplikasi Basis Data dengan Visual Basic .NET, Cetakan Pertama, Penerbit Informatika, Bandung, 2014.

Kuncoro, D. W. (2015). Analisis Dan Perancangan Sistem Kasir Dan Pendataan Stok Barang Pada Tata Distro Pacitan. 7(1), 40-46.

Marisa, F., \& Yuarita, T. G. (2017). Perancangan Aplikasi Point of Sales (Pos) Berbasis Web Menggunakan Metode Siklus Hidup Pengembangan Sistem. Jurnal Teknologi Dan Manajemen Informatika, 3(2), 167171.

https://doi.org/10.26905/jtmi.v3i2.151 4

Pamungkas, G., \& Yuliansyah, H. (2017). Rancang Bangun Aplikasi Android Pos (Point of Sale) Kafe Untuk Kasir Portable Dan Bluetooth Printer. JST (Jurnal Sains Dan Teknologi), 6(1), 199-208. https://doi.org/10.23887/jstundiksha.v6i1.8828

Siddik, M., \& Sirait, A. (2018). Pengembangan Sistem Informasi Administrasi Akademik Dengan Rancangan Modul Program Menggunakan Bahasa Pemrograman Berorientasi Objek. 2(1), 51-57.

Sutarman, S.Kom, M.Kom, Pengantar Teknologi Informasi, Cetakan Pertama, Penerbit PT. Bumi Aksara, Jakarta, 2009. 